\title{
Anion and water involvement in hydrous Ir oxide redox reactions in acidic solutions
}

\author{
C. Bock*, V.I. Birss \\ Department of Chemistry, University of Calgary, Calgary, Alta, T2N 1N4, Canada
}

Received 9 April 1999; received in revised form 7 July 1999; accepted 27 July 1999

\begin{abstract}
The stoichiometry of the Ir oxide reaction in sulfuric acidic solutions was investigated by tracking the $\mathrm{pH}$ dependence of its principal $\operatorname{Ir}(+\mathrm{III}) / \operatorname{Ir}(+\mathrm{IV})$ redox peaks, as well as monitoring the film mass change with in-situ quartz crystal microbalance measurements. A pH dependence of ca. $-68 \mathrm{mV}$ versus a $\mathrm{pH}$ independent reference electrode was found for films grown by potential pulsing using a wire electrode, indicating the injection/expulsion of protons and some solution anions during film reduction/oxidation. The unaccounted mass change was interpreted as being due to water flux in/out of the film. The pH dependence, and hence, the ion stoichiometry appears to be independent of the acidic solution used to grow the Ir oxide film, while the acidic solution in which the oxide is cycled between its reduced and oxidized states appears to influence the $\operatorname{Ir}(+$ III $) / \operatorname{Ir}(+$ IV) reaction stoichiometry. Crown copyright (C) 1999 Published by Elsevier Science S.A. All rights reserved.

Keywords: Redox reaction; Iridium oxide
\end{abstract}

\section{Introduction}

Hydrous Ir oxide films have attracted much attention due to their potential use as electrochromic devices $[1,2]$, supercapacitors $[3,4]$ and interneural stimulating electrodes [5]. Ir oxide films up to several microns in thickness and exhibiting high film charge densities can be grown on Ir metal substrates by continuous potential cycling or pulsing in aqueous solutions using specific upper and lower potential limits [6-8]. Electrochemically formed $\mathrm{Ir}$ oxide films respond in a super-Nernstian manner, seen as a $>|59| \mathrm{mV} / \mathrm{pH}$ dependence (vs. a $\mathrm{pH}$ independent reference electrode) of the principal anodic and cathodic peaks, when examined using slow sweep cyclic voltammetry $(\mathrm{CV})$ at $25^{\circ} \mathrm{C}$ [9]. This behavior has caused some controversy concerning the nature of the species involved during the electrochemical $\operatorname{Ir}(+\mathrm{III}) / \operatorname{Ir}(+\mathrm{IV})$ reaction of these films $[9,10]$. Some researchers $[10,11]$ have suggested that, in acidic solutions, protons and anions, and in basic solutions, hydroxide ions and cations, are involved during the reaction in order to maintain

\footnotetext{
* Corresponding author. Present address: National Research Coun-
} cil Canada, Montreal Road, Ottawa, Ontario, K1A 0R6, Canada. electroneutrality within the films. However, other thermodynamic changes of Ir oxide film properties, such as a differing interaction energy between redox sites in the oxidized versus reduced form, can also introduce a non-Nernstian behavior [12,13], and hence, additional studies are required to understand the $E / \mathrm{pH}$ response of these films.

Electrochemical quartz crystal microbalance measurements (EQCM) have been used to study the ion/ solvent expulsion/injection processes which accompany the electrochemical conversion reactions of materials such as redox polymers and hydrous metal oxide films $[14,15]$. This technique has also been used to study Ir oxide films grown electrochemically in $0.2 \mathrm{M} \mathrm{H}_{2} \mathrm{SO}_{4}$, and then studied in the same solution or in $0.2 \mathrm{M} \mathrm{KOH}$ [16]. A reversible film mass loss of ca. $6 \mathrm{~g} \mathrm{~mol}^{-1}$ Ir sites in the oxide film was found to accompany the $\operatorname{Ir}(+$ III) to $\operatorname{Ir}(+\mathrm{IV})$ reaction in the acidic solution, whereas in the basic medium, a smaller mass change of opposite sign (i.e. mass gain) of ca. $3 \mathrm{~g} \mathrm{~mol}^{-1}$ Ir was found during film oxidation. These results suggested that, during oxidation to $\operatorname{Ir}(+\mathrm{IV})$, protons are expelled from the film in acidic solutions, while hydroxide ions are injected into the film in $\mathrm{KOH}$. Additionally, the magnitude of the mass changes indicated that not only pro- 
tons and hydroxide ions are involved during the $\operatorname{Ir}(+$ III) $/ \operatorname{Ir}(+$ IV) conversion reaction, but that counter anions (in acid) and cations (in base), and/or $\mathrm{H}_{2} \mathrm{O}$, may be injected/expelled. The involvement of counter anions/ cations in the reaction would be consistent with the model proposed by Pickup and Birss [10], suggested on the basis of the super-Nernstian response of electrochemically grown Ir oxide films and the chemical analysis of the ionic content of the fully oxidized versus reduced Ir oxide films.

In the present research, the $\mathrm{pH}$ response of $\mathrm{Ir}$ oxide films grown in $\mathrm{H}_{2} \mathrm{SO}_{4}, \mathrm{HClO}_{4}$ and $\mathrm{HNO}_{3}$ solutions is reported. The observed $E / \mathrm{pH}$ response is also compared with literature values, as well as examined in terms of factors which can introduce a super-Nernstian $(>|59|$ $\mathrm{mV} / \mathrm{pH})$ response. These factors include the acid/base character of the $\operatorname{Ir}(+\mathrm{III}) / \operatorname{Ir}(+\mathrm{IV})$ forms of the oxide, and changes in the interaction energies of redox sites. Mass changes during the reduction/oxidation of Ir oxide films, grown and studied in a range of acidic solutions, were determined and compared to the experimental $E / \mathrm{pH}$ response, as well as to previously reported EQCM data.

\section{Experimental}

\subsection{Electrodes and cell}

Ir oxide films were formed electrochemically on either polycrystalline $\mathrm{Ir}$ wires $(1 \mathrm{~mm}$ diameter, $1 \mathrm{~cm}$ length, $99.9 \%$ purity, Johnson-Matthey) or on $\mathrm{Ti} / \mathrm{Ir}$ sputtercoated $5 \mathrm{MHz}$ AT-cut quartz crystals $(2.5 \mathrm{~cm}$ diameter, Valpey-Fisher). The quartz crystals were sputter-coated on both sides in a keyhole pattern, first with a ca. $80 \mathrm{~nm}$ Ti layer and then with a ca. $50 \mathrm{~nm}$ Ir layer. A Denton Vacuum DV-502A system was employed to sputtercoat the crystals in an argon atmosphere. The Ti was sputtered for $100 \mathrm{~s}$ at ca. $0.4 \mathrm{~A}$, whereas the Ir was sputtered for $6.5 \mathrm{~min}$. at ca. $0.1 \mathrm{~A}$. Au wires were attached to the edges of the Ir keyhole-shaped coating on the crystal with conducting Ag epoxy (2400 Circuit Works kit, distributed by Allied Electronics) to provide electrical contact.

Ir oxide flms were grown in $0.4 \mathrm{M} \mathrm{H}_{2} \mathrm{SO}_{4}, 0.6 \mathrm{M} \mathrm{HClO}_{4}$ and $0.4 \mathrm{M} \mathrm{HNO}_{3}$ solutions by either potential cycling at $100 \mathrm{mV} \mathrm{s}^{-1}$ or applying potential pulses of $2 \mathrm{~s}$ duration between 1.2 and $-0.3 \mathrm{~V}$ versus a saturated sodium chloride calomel electrode (SSCE). The equilibrium CV characteristics in all growth solutions were very similar. In fact, oxidation and reduction peak potentials $\left(E_{\mathrm{A}_{1}}\right.$ and $E_{\mathrm{C}}$, respectively) were $0.68 \mathrm{~V}$, and the anodic and cathodic peak half-widths measured at the peak halfheight of $\mathrm{A}_{1}$ and $\mathrm{C}_{1}$ (i.e. $E_{(1 / 2) \mathrm{A}}$ and $E_{(1 / 2) \mathrm{C}_{1}}$ ) were $140 \pm 5$ $\mathrm{mV}$ in these three solutions. The equilibrium film charge densities $(q)$ were estimated from the anodic charge passed in a slow sweep $\mathrm{CV}$ to $E_{\mathrm{A}_{1}}+0.22 \mathrm{~V}$ and are estimated within an error of $\pm 5 \%$. It is assumed here that only $\operatorname{Ir}(+\mathrm{III})$ and $\operatorname{Ir}(+\mathrm{IV})$ states are stable in this potential range, i.e., that each electron passed reflects the electrochemical conversion of one Ir site between the $(+$ III) and ( + IV) states [17]. Previously grown Ir oxide films were removed by anodic dissolution in $2 \mathrm{M} \mathrm{H}_{2} \mathrm{SO}_{4}$ [8].

Standard two compartment glass cells, in which the reference electrode compartment was connected to the working electrode (WE) compartment containing also a high area Pt mesh counter electrode, through a Luggin capillary, were employed to grow and study the Ir oxide films. An SSCE or a reversible hydrogen electrode (RHE) was employed as the reference electrode and all potentials reported in this work are referred to the SSCE. The WE compartment utilized in the EQCM studies differed in construction from the standard cell generally employed. The quartz crystal working electrode was sandwiched between the open-ended, circular base of the working compartment of the EQCM cell and a glass tube. Two rubber O-rings were placed between the crystal and the two glass interfaces to prevent leakage of the solution, and a ball and socket clamp (no. 28, VWR Scientific) was used to hold the two compartments together.

\subsection{Equipment}

A Jaissle potenstiostat/galvanostat IMP 83 and an EG\&G PARC 175 function generator were employed. An EQCM system was utilized to measure the oxide film mass changes by monitoring changes in the resonance frequency of the quartz oscillator. The home-built oscillator was powered by a $3 \mathrm{~V} \mathrm{dc}$ source and the crystal frequency changes were tracked by a Philipps PM 6654C high resolution frequency timer/counter. A resolution of $1-0.1 \mathrm{~Hz}$ was achieved using integration periods of $1-10$ s. The frequency and current responses were plotted versus potential on BBC Goerz Metrawatt SE 780 recorders.

All chemicals used in this work were A.C.S. analytical grade. The water was deionized and distilled using a Corning MEGA-Pure MP-6A system and had a resistivity of ca. $18 \mathrm{M} \Omega \mathrm{cm}^{-1}$. The solutions for the electrochemical system were generally deoxygenated using high purity nitrogen gas and all experiments were carried out at room temperature, i.e. $20 \pm 2^{\circ} \mathrm{C}$.

\section{Results and discussion}

\subsection{The E/pH response: thermodynamic issues}

The super-Nernstian $E / \mathrm{pH}$ response of hydrous, electrochemically formed Ir oxide films and other similar systems has been suggested to be due to the different 
acid/base characteristics of the oxidized and reduced oxide states [9]. This results in the expulsion/injection of more than one proton or hydroxide ion, per electron passed, with charge compensation then accomplished by additional solution ions, e.g. in acidic solutions:

$$
\begin{aligned}
\operatorname{Ir}(+\mathrm{III}) \text { oxide }= & \operatorname{Ir}(+\mathrm{IV}) \text { oxide }+x \mathrm{H}^{+} \\
& +(x-1) \mathrm{A}^{-}+\mathrm{e}^{-}
\end{aligned}
$$

The potential $(E)$ of the $\operatorname{Ir}(+\mathrm{III}) / \operatorname{Ir}(+\mathrm{IV})$ reaction would then be defined as follows [10], assuming that the classical form of the Nernst equation applies [9]:

$E=E^{\circ}+\frac{R T}{F} \ln \frac{[\operatorname{Ir}(+\mathrm{IV}) \text { oxide }]\left[\mathrm{H}^{+}\right]^{x}\left[\mathrm{~A}^{-}\right]^{x-1}}{[\operatorname{Ir}(+\mathrm{III}) \text { oxide }]}$

Eq. (2) can be rearranged to:

$$
\begin{aligned}
E= & E^{\circ}+\frac{2.3 R T}{F} \log \frac{X_{\mathrm{O}}}{\left(1-X_{\mathrm{O}}\right)}-\frac{2.3 R T}{F} \times \mathrm{pH} \\
& -\frac{2.3 R T}{F} \log \left[\mathrm{A}^{-}\right]^{x-1}
\end{aligned}
$$

In Eq. (2) and Eq. (3), $X_{\mathrm{O}}$ is the fraction of the active Ir sites in the oxide which are in the oxidized state and, $x$ indicates the number of protons which are expelled from and injected into the oxide film per $\operatorname{Ir}(+\operatorname{III}) \operatorname{Ir}(+\mathrm{IV})$ site (i.e. per $\mathrm{e}^{-}$) converted and $\left[\mathrm{A}^{-}\right]$represents the acitivity of univalent counter anions ( $\left.\mathrm{A}^{-}\right)$. All other symbols in Eqs. (2) and (3) have their usual meaning. Eq. (3) shows that an increase in solution $\mathrm{pH}$ shifts $E$ negatively and vice versa, a decrease in solution $\mathrm{pH}$ shifts $E$ positively.

The classical form of the Nernst equation (Eqs. (2) and (3)) correctly describes the dependence of $E$ of Ir oxide films on the solution $\mathrm{pH}$ when their properties (other than the acid/base characteristics of the oxidized and the reduced film forms) are unaltered by the electrochemical reaction and the test solution composition. It should be noted that changes in the interaction energy between redox sites and alterations in the chemical potential of the counter ions and/or other species within the oxide film could also cause a shift in the $E$ value $[12,13]$. This would also result in a non-Nernstian $E / \mathrm{pH}$ response, even for the case when only one proton per electron is involved during the electrochemical conversion reaction $[12,13]$. However, this would predict a change in peak shape (symmetry or peak separation $\left(E_{\mathrm{A}_{1}}-E_{\mathrm{C}_{1}}\right)$ ) with $\mathrm{pH}$. As this is not seen in the present work (see below), this explanation can be ruled out for the case of Ir oxide films.

\subsection{Determination of the $E / p H$ response for Ir oxide films in solutions of low $\mathrm{pH}$ : general experimental procedure}

In the present work, the $E / \mathrm{pH}$ response of ca. 35 $\mathrm{mC} \mathrm{cm}{ }^{-2}$ Ir oxide films, grown in $0.4 \mathrm{M} \mathrm{H}_{2} \mathrm{SO}_{4}, 0.6 \mathrm{M}$
$\mathrm{HClO}_{4}$ and $0.4 \mathrm{M} \mathrm{HNO}_{3}$ solutions by potential pulsing, was measured. All potential measurements were carried out in constant ionic strength solutions made of $\mathrm{H}_{2} \mathrm{SO}_{4}+\mathrm{Na}_{2} \mathrm{SO}_{4}$ versus the RHE, assuming that the potential of the RHE shifts exactly $-59 \mathrm{mV}$ per $\mathrm{pH}$ unit at $25^{\circ} \mathrm{C}[17,18]$. The test solution concentrations ranged between $10^{-2}$ and $0.75 \mathrm{M} \mathrm{H}_{2} \mathrm{SO}_{4}, 0$ and 0.74 $\mathrm{M} \mathrm{Na} \mathrm{Na}_{4}$. The approximate solution $\mathrm{pH}$ range was between 0.5 and 2, as indicated by the measured potential difference between the SSCE and RHE (ignoring liquid junction potentials). The Ir oxide films were equilibrated in the test solution by first cycling the potential at $20 \mathrm{mV} / \mathrm{s}$ for 10 full cycles and then at a sweep rate $(s)$ low enough so that $I_{\mathrm{p}} \propto s$ until steadystate $E_{\mathrm{A}_{1}}$ and $E_{\mathrm{C}_{1}}$ values were reached, which occurred rapidly. In fact, $E_{\mathrm{A}}$ and $E_{\mathrm{C}}$, were found to reach constant values rapidly even when the oxide films were transferred between $0.5 \mathrm{M} \mathrm{H}_{2} \mathrm{SO}_{4}$ and $1 \mathrm{M} \mathrm{KOH}$ solutions. This indicates that protonation and deprotonation of Ir sites within the film occurs rapidly, without the need to multicycle the films between the $\operatorname{Ir}(+\mathrm{III}) / \operatorname{Ir}(+\mathrm{IV})$ states. Also, the Ir oxide films were cycled between an upper potential limit $\left(E_{+}\right)$less positive than $E_{\mathrm{A}_{1}}+0.5 \mathrm{~V}$ and a lower potential limit $\left(E_{-}\right)$ more positive than $E_{\mathrm{A}_{1}}-0.7 \mathrm{~V}$ in these experiments. These $E_{+}$and $E_{-}$values were selected to avoid dissolution of the oxide, as well as any irreversible aging effects frequently observed with these films when subjected to negative potentials [19].

Before and after the $E / \mathrm{pH}$ responses were determined in each test solution, slow sweep CVs of the films were recorded in the growth solution. The $\mathrm{CV}$ characteristics of the $\operatorname{Ir}(+\mathrm{III}) / \operatorname{Ir}(+\mathrm{IV})$ main charge storage reaction $\left(\mathrm{A}_{1}\right.$ and $\left.\mathrm{C}_{1}\right)$ observed in the growth solution were found to be uninfluenced by the fact that the oxide films had been cycled in different solutions. Identical values of $E_{\mathrm{A}_{1}}, E_{\mathrm{C}_{1}}$ and equilibrium film charge densities were found before and after the $E / \mathrm{pH}$ measurements. This shows that the film properties defining the $E / \mathrm{pH}$ behavior are not irreversibly altered by the test solutions. The $E_{\mathrm{A}_{1}}$ and $E_{\mathrm{C}_{1}}$ values were found to be highly reproducible, with potentials varying by less than $\pm 3 \mathrm{mV}$.

\subsubsection{E/pH response of Ir oxide firms grown in $\mathrm{H}_{2} \mathrm{SO}_{4}$ solutions}

The CVs for ca. $35 \mathrm{mC} \mathrm{cm}{ }^{-2} \mathrm{Ir}$ oxide films grown in $0.4 \mathrm{M} \mathrm{H}_{2} \mathrm{SO}_{4}$ and subsequently cycled at $1 \mathrm{mV} \mathrm{s}^{-1}$ in the same solution and then in one of two test solutions, 0.05 $\mathrm{M} \mathrm{H}_{2} \mathrm{SO}_{4}+0.74 \mathrm{M} \mathrm{Na}_{2} \mathrm{SO}_{4}$ and $0.05 \mathrm{M} \mathrm{H}_{2} \mathrm{SO}_{4}$, are shown in Fig. 1. In these CVs, the current is plotted versus the applied potential $(E)-E_{\mathrm{A}}$, for the oxide film in the corresponding solution to enable better comparison of the data. The following $E_{\mathrm{A}}$ values were found for these films: $0.68 \mathrm{~V}$ in $0.4 \mathrm{M} \mathrm{H}_{2} \mathrm{SO}_{4}, 0.59 \mathrm{~V}$ in 
$0.05 \mathrm{M} \mathrm{H}_{2} \mathrm{SO}_{4}+0.74 \mathrm{M} \mathrm{Na}_{2} \mathrm{SO}_{4}$ and $0.62 \mathrm{~V}$ in $0.05 \mathrm{M}$ $\mathrm{H}_{2} \mathrm{SO}_{4}$, consistent with the change in solution $\mathrm{pH}$. Also, newly formed Ir oxide films were employed for each of the two test solutions. Fig. 1 shows that the $E_{(1 / 2) \mathrm{A}_{1}}$ and $E_{(1,2) C_{1}}$ values are very similar in all these solutions. Also, the symmetry of peaks $\mathrm{A}_{1}$ and $\mathrm{C}_{1}$ are uninfluenced by the test solution. This indicates that the values of $X_{\mathrm{O}} /\left(1-X_{\mathrm{O}}\right)$ at the peak maxima are identical for all test solutions used in this work and that changes in $X_{\mathrm{O}} /\left(1-X_{\mathrm{O}}\right)$ not contribute to the experimentally observed $E / \mathrm{pH}$ response (Eqs. (2) and (3)).

An additional small cathodic peak $\left(\mathrm{C}_{\mathrm{O}}\right)$ is observed in the $\mathrm{CV}$ for the Ir oxide films studied in the two test solutions at more negative potentials. This peak is often observed when Ir oxide films are studied at slow sweep rates, especially when cycled between different potential limits than those employed for film growth [20]. This peak, which corresponds to the anodic $A_{O}$ peak [21], appears not to influence the main charge storage reaction, since the equilibrium film charge density is not affected, as shown in Fig. 1.

The influence of the test solution concentration on the $E / \mathrm{pH}$ dependence was also investigated for ca. 35 $\mathrm{mC} \mathrm{cm}{ }^{-2} \mathrm{Ir}$ oxide films grown in $\mathrm{H}_{2} \mathrm{SO}_{4}$. Solutions of constant ionic strength, made up with $\mathrm{H}_{2} \mathrm{SO}_{4}+\mathrm{Na}_{2} \mathrm{SO}_{4}$ or only $\mathrm{H}_{2} \mathrm{SO}_{4}$ solutions were used. Fig. 2 shows the dependence of $E_{\mathrm{C}_{1}}$ on $E_{\mathrm{RHE}}-E_{\mathrm{SSCE}}$ for the different test solutions. A very similar $E / \mathrm{pH}$ response of ca. $-68 \mathrm{mV} / \mathrm{pH}( \pm 3 \mathrm{mV} / \mathrm{pH})$ was found in the two cases, suggesting that the $\mathrm{Na}^{+}$cation does not influence the electrochemical conversion reaction, consistent with re-

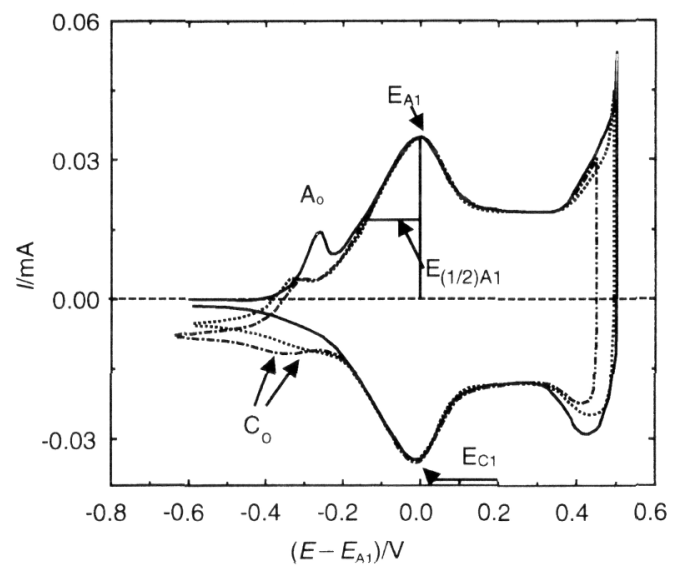

Fig. 1. The influence of the test solution $\mathrm{pH}$ and composition on the

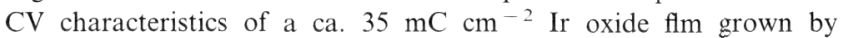
pulsing the potential for $2 \mathrm{~s}$ between 1.2 and $-0.3 \mathrm{~V}$ in $0.4 \mathrm{M}$ $\mathrm{H}_{2} \mathrm{SO}_{4}$. Subsequent cycling (-) at $2 \mathrm{mV} \mathrm{s}^{-1}$ in $0.4 \mathrm{M} \mathrm{H}_{2} \mathrm{SO}_{4}$ between 1.2 and $-0.3 \mathrm{~V} ;(---)$ at $1 \mathrm{mV} \mathrm{s}^{-1}$ in $0.05 \mathrm{M} \mathrm{H}_{2} \mathrm{SO}_{4}$ between 1.05 and $0 \mathrm{~V}$; (-----) at $1 \mathrm{mV} \mathrm{s}^{-1}$ in $0.05 \mathrm{M} \mathrm{H}_{2} \mathrm{SO}_{4}+0.7 \mathrm{M}$ $\mathrm{Na}_{2} \mathrm{SO}_{4}$ between 1.15 and $0 \mathrm{~V}$. All CVs were recorded after 10 cycles at $20 \mathrm{mV} \mathrm{s}^{-1}$ in the new test solution between the corresponding limits and then holding the potential at $E_{-}$for $10 \mathrm{~min}$. Note that the current scale for the Ir oxide film cycled in $0.4 \mathrm{M} \mathrm{H}_{2} \mathrm{SO}_{4}$ at $2 \mathrm{mV} \mathrm{s}^{-1}$ (-) has been divided by 2 to give a better comparison of the data.

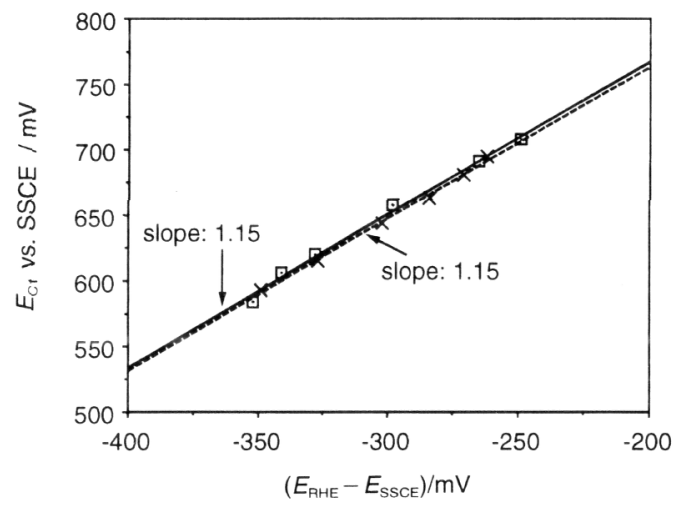

Fig. 2. The $\mathrm{mV} / \mathrm{pH}$ response of $E_{\mathrm{C}_{1}}$ for ca. $35 \mathrm{mC} \mathrm{cm}^{-2} \mathrm{Ir}$ oxide films, grown by pulsing the potential for $2 \mathrm{~s}$ between 1.2 and $-0.3 \mathrm{~V}$ in $0.4 \mathrm{M} \mathrm{H}_{2} \mathrm{SO}_{4}$, as a function of the test solution composition. ( $\square$ ) $\mathrm{H}_{2} \mathrm{SO}_{4}+\mathrm{Na}_{2} \mathrm{SO}_{4}$ solutions, (x) in $\mathrm{H}_{2} \mathrm{SO}_{4}$ solutions.

action (1). Furthermore, it is noteworthy that the $E_{\mathrm{A}_{1}}$ and $E_{\mathrm{C}_{1}}$ values measured directly versus the RHE also yielded a $-68 \mathrm{mV} / \mathrm{pH}$ response.

The observed $E / \mathrm{pH}$ response of $-68 \mathrm{mV} / \mathrm{pH}$ is smaller than the ca. $-90 \mathrm{mV} / \mathrm{pH}$ observed $[9,22]$ over a broad range of $\mathrm{pH}(1-12)$ and that reported by Pickup and Birss of $-82 \mathrm{mV} / \mathrm{pH}$, measured over a narrow $\mathrm{pH}$ range (ca. 1.5-2.5) [10]. It should be noted that over a large $\mathrm{pH}$ range ( $>6 \mathrm{pH}$ units) the $E_{(1 / 2) \mathrm{A}}$ and $E_{(1 / 2) C}$ values are also altered by more than 100 $\mathrm{mV}$ [22]. This indicates that the classical form of the Nernst equation (Eqs. (2) and (3)) does not account for all of the factors influencing the dependence of $E$ on the solution $\mathrm{pH}[9,12,13]$, thus explaining the different $E$ / $\mathrm{pH}$ responses observed in prior work. Also the work [10], however, investigated Ir oxide films grown and examined in different (buffered) solutions from those used here and involved only three $\mathrm{pHs}$ in the acidic range, which may have introduced some error.

The value of $-68 \mathrm{mV} / \mathrm{pH}$ obtained in the present work in the $\mathrm{H}_{2} \mathrm{SO}_{4}$ containing test solutions suggests that more than one proton per Ir site oxidized/reduced is expelled/injected from/into the hydrous Ir oxide films. Therefore, some counter anion (assumed to be $\mathrm{HSO}_{4}^{-}$) expulsion/injection must occur to maintain electroneutrality within the Ir oxide films. The classical form of the Nernst equation (Eq. (3)) yields the relationship between the number of protons involved per each electron passed $(x)$ and the $E / \mathrm{pH}$ response (i.e. the shift in the equilibrium peak potential $\left(\Delta E_{\mathrm{C}_{1}}\right)$ with solution $\mathrm{pH}$ ), as follows:

$x=\frac{-\Delta E_{\mathrm{C}_{1}}}{\Delta \mathrm{pH}} \frac{F}{2.3 R T}=\frac{0.068 \mathrm{~V}}{0.059 \mathrm{~V}}=1.15$

Therefore, the experimental $E / \mathrm{pH}$ response of -68 $\mathrm{mV} / \mathrm{pH}$ suggests that $1.15 \mathrm{H}^{+}$and $0.15 \mathrm{HSO}_{4}^{-}(x-1=$ $0.15 \mathrm{~A}^{-}$(Eq. (3)) are involved in the $\operatorname{Ir}(+\mathrm{III}) / \operatorname{Ir}(+\mathrm{IV})$ reaction in $\mathrm{H}_{2} \mathrm{SO}_{4}$ solutions of low $\mathrm{pH}$ (ca. 0.5-2). 
Note that changes in the activity of the univalent counter anion $\left(\mathrm{A}^{-}\right)$are ignored, based on the independence of the $E / \mathrm{pH}$ response from the $\mathrm{HSO}_{4}^{-}$concentration of the test solutions. It is also noteworthy that both $E_{\mathrm{A}_{1}}$ and $E_{\mathrm{C}_{1}}$ are independent of the film charge density for Ir oxide films $>1 \mathrm{mC} \mathrm{cm}^{-2}$ [19], indicating that the $E / \mathrm{pH}$ response for these films is also independent of the film charge.

\subsubsection{Experimental $E / p H$ response of Ir oxide films} formed in different acidic solutions

Fig. 3 shows the experimental $E / \mathrm{pH}$ responses for Ir oxide films grown in $0.6 \mathrm{M} \mathrm{HClO}_{4}, 0.4 \mathrm{M} \mathrm{H}_{2} \mathrm{SO}_{4}$ and $0.4 \mathrm{M} \mathrm{HNO}_{3}$. The $E / \mathrm{pH}$ responses of these films were obtained in $\mathrm{H}_{2} \mathrm{SO}_{4}+\mathrm{Na}_{2} \mathrm{SO}_{4}$ solutions. Similar $E / \mathrm{pH}$ values of ca. $-68 \mathrm{mV} / \mathrm{pH}$ were found for these $\mathrm{Ir}$ oxide films, suggesting that it is the Ir oxide (and perhaps partly the nature of the test solution anion $\left.\left(\mathrm{HSO}_{4}^{-}\right)\right)$which defines the acid-base character of these oxide films.

\subsection{EQCM measurements}

\subsubsection{General frequency response during}

oxidation/reduction of Ir oxide firms in acidic solutions

For the EQCM studies, all Ir oxide films were grown on Ir sputter-coated $5 \mathrm{MHz}$ quartz crystals in $0.4 \mathrm{M}$ $\mathrm{H}_{2} \mathrm{SO}_{4}, 0.6 \mathrm{M} \mathrm{HClO}_{4}$ and $0.4 \mathrm{M} \mathrm{HNO}_{3}$ by either potential cycling or pulsing between 1.2 and $-0.3 \mathrm{~V}$ for 4-80 min. Equilibrium film charge densities of ca. $2-7 \mathrm{mC} \mathrm{cm}^{-2}$ were achieved. The Ir oxide films were rinsed with ca. $200 \mathrm{ml} \mathrm{H}_{2} \mathrm{O}$ before transferring them

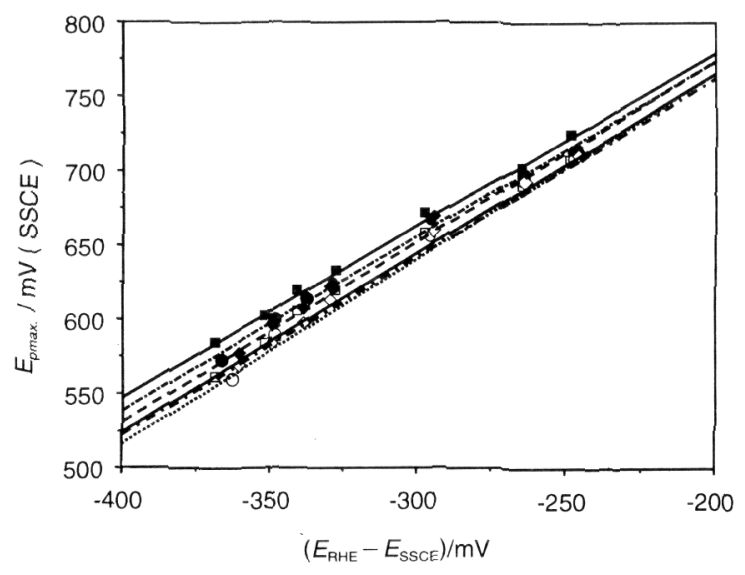

Fig. 3. The $\mathrm{mV} / \mathrm{pH}$ response for ca. $35 \mathrm{mC} \mathrm{cm}^{-2}$ Ir oxide films, grown by pulsing the potential for $2 \mathrm{~s}$ between 1.2 and $-0.3 \mathrm{~V}$ in a range of acidic solutions, and determined in $\mathrm{H}_{2} \mathrm{SO}_{4}+\mathrm{Na}_{2} \mathrm{SO}_{4}$ solutions of constant ionic strength. (ם) and $(\square) E_{\mathrm{A}_{1}}$ and $E_{\mathrm{C}_{1}}$, respectively, for oxide films grown in $0.4 \mathrm{M} \mathrm{H}_{2} \mathrm{SO}_{4} ;(\bullet)$ and $(0) E_{\mathrm{A}_{1}}$ and $E_{\mathrm{C}_{1}}$, respectively, for oxide films grown in $0.4 \mathrm{M} \mathrm{HClO}_{4} ;(\diamond)$ and $(\diamond)$ $E_{\mathrm{A}_{1}}$ and $E_{\mathrm{C}_{1}}$, respectively, for oxide films grown in $0.4 \mathrm{M} \mathrm{HNO}_{3}$. The lines represent the best linear fit to the experimental data: $(-)$ oxide films grown in $0.4 \mathrm{M} \mathrm{H}_{2} \mathrm{SO}_{4}$; (- - ) oxide films grown in $0.6 \mathrm{M}$ $\mathrm{HClO}_{4}$; (-----) oxide films grown in $0.4 \mathrm{M} \mathrm{HNO}_{3}$.
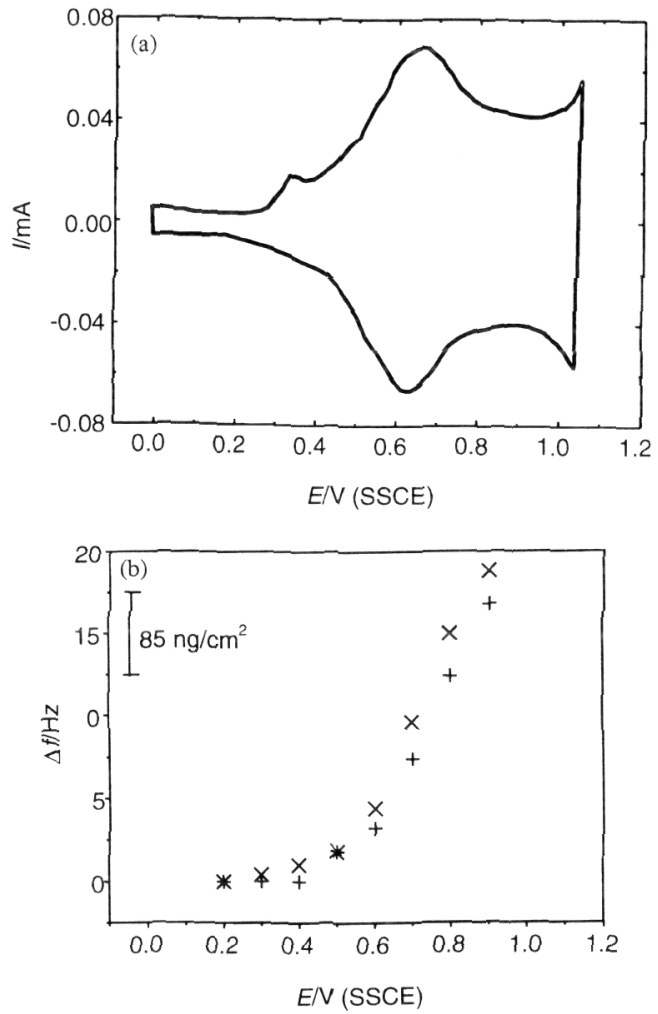

Fig. 4. CV (Fig. 4a) and selected frequency data (Fig. 4b) for a ca. 3.5 $\mathrm{mC} \mathrm{cm}{ }^{-2} \mathrm{Ir}$ oxide film grown and cycled at $10 \mathrm{mV} \mathrm{s}^{-1}$ between 1.05 and $0 \mathrm{~V}$ in $0.4 \mathrm{M} \mathrm{H}_{2} \mathrm{SO}_{4}$. $((+)$ data collected during oxidation scan; (x) during reduction scan).

between solutions in their partially oxidized state, i.e. at the open-circuit potential of ca. $670 \mathrm{mV}$. The mass change per mole of Ir sites oxidized/reduced $(\Delta m / \mathrm{mol}$ Ir) was estimated from the mass and charge passed between 0.2 and $0.9 \mathrm{~V}$, using $s<$ the equilibrium sweep rate $\left(s_{\mathrm{eq}}\right)$, which allows full film charge recovery [23]. The $\Delta m / \mathrm{mol}$ Ir value and the absolute film mass were generally constant with repeated cycling and independent of $s$, unless otherwise stated. The $\Delta m / \mathrm{mol}$ Ir values for an individual oxide film were highly reproducible (i.e. $\pm 0.08 \mathrm{~g}$ per $\mathrm{mol} \mathrm{Ir}$ ), whereas a larger error of ca. $\pm 0.5 \mathrm{~g}$ per mol Ir was found for Ir oxide films grown in identical solutions, but on different crystals.

A typical CV for a ca. $3.5 \mathrm{mC} \mathrm{cm}{ }^{-2} \mathrm{Ir}$ oxide film formed on an Ir sputter-coated quartz crystal in $0.4 \mathrm{M}$ $\mathrm{H}_{2} \mathrm{SO}_{4}$ by potential pulsing is shown in Fig. 4a. The voltammetric characteristics are identical to the response of oxides formed on an Ir wire substrate, thus justifying the comparison of these oxide films. Fig. $4 \mathrm{~b}$ shows the typical frequency change $(\Delta f)$ accompanying the $\operatorname{Ir}(+\mathrm{III}) / \operatorname{Ir}(+\mathrm{IV})$ reaction for the $\mathrm{Ir}$ oxide film grown and then cycled at $10 \mathrm{mV} \mathrm{s}^{-1}$ between 0 and $1.05 \mathrm{~V}$ in $0.4 \mathrm{M} \mathrm{H}_{2} \mathrm{SO}_{4}$. This response is consistent with the reaction shown in Eq. (1), since an increase in the frequency (observed during oxidation) indicates that the film mass decreases, consistent with proton expul- 
sion from the film, and vice versa, a decrease in the frequency (observed during reduction) indicates that the film mass increases due to proton injection (Eq. (1)). It should be noted that other species may also contribute to these mass changes (see below).

The change in frequency was converted to mass change using the Sauerbrey equation, and a proportionality constant of $56.6 \mathrm{~Hz} \mathrm{\mu g}{ }^{-1} \mathrm{~cm}^{-2}$ [24]. This relationship is valid for thin and rigid films [24]. Birss et al. [16] have shown that this condition is fulfilled for hydrous Ir oxide films in the range of $1-40 \mathrm{mC} \mathrm{cm}^{-2}$, as indicated by the linear relationship found between the equilibrium film charge density and the frequency change observed during potential cycling. In this work, the Ir oxide films studied were actually very thin (ca. 40-100 $\mathrm{nm}[20]$ ). The linear relationship found between the $q$ and $\Delta f$ data is shown in Fig. 5 for the ca. $3-8 \mathrm{mC}$ $\mathrm{cm}^{-2} \mathrm{Ir}$ oxide films grown in $0.4 \mathrm{M} \mathrm{H}_{2} \mathrm{SO}_{4}$ by potential pulsing between 4 and $16 \mathrm{~min}$, and then cycled at 10 $\mathrm{mV} \mathrm{s}^{-1}$ between 1.05 and $0 \mathrm{~V}$. Extrapolation to zero equilibrium film charge density results in a close to zero $\Delta f(\mathrm{ca} .0-1 \mathrm{~Hz})$ intercept, as similarly found by Birss et al. [15]. This justifies the application of the Sauerbrey equation to the Ir oxide films studied here.

\subsection{2. $4 \mathrm{~m} / \mathrm{mol} \mathrm{Ir}$ values measured in $0.4 \mathrm{M} \mathrm{H}_{2} \mathrm{SO}_{4}$}

In this section, the $\Delta m / \mathrm{mol}$ Ir values for the ca. 3.5-7 $\mathrm{mC} \mathrm{cm}^{-2}$ Ir oxide films, grown by potential pulsing in $0.4 \mathrm{M} \mathrm{H}_{2} \mathrm{SO}_{4}$ and then cycled (in the growth solution) between 1.05 and $0 \mathrm{~V}$, were obtained. The fact that several ionic species plus water may contribute to the mass change of these oxide films complicates the interpretation of the EQCM data (see below). In the following, the EQCM data is analyzed in terms of the protonic/anionic stoichiometry obtained from the measured $\mathrm{pH}$ dependence (see above). To fit the $\Delta m / \mathrm{mol}$ Ir data to the observed $E / \mathrm{pH}$ response, the expulsion/injection of $\mathrm{H}^{+}$is assumed. However, the data could also

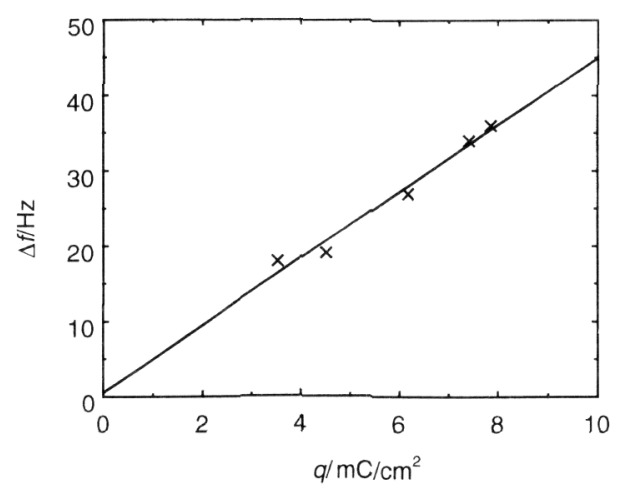

Fig. 5. Frequency change measured during the conversion between the reduced $(0.2 \mathrm{~V})$ and oxidized $(0.9 \mathrm{~V})$ states of Ir oxide films, grown and studied $\left(10 \mathrm{mV} \mathrm{s}^{-1}\right)$ in $0.4 \mathrm{M} \mathrm{H}_{2} \mathrm{SO}_{4}$ versus the equilibrium film charge density. The solid line shows the best linear fit to the experimental data $(\mathrm{x})$. be interpreted as reflecting one $\mathrm{H}_{2} \mathrm{O}$ injected into the film for each $\mathrm{H}_{3} \mathrm{O}^{+}$expelled during the $\operatorname{Ir}(+\mathrm{III})$ to $\operatorname{Ir}(+\mathrm{IV})$ oxidation process, and vice versa, during reduction. In fact, $\mathrm{H}_{3} \mathrm{O}^{+}$rather than $\mathrm{H}^{+}$, is the more likely species to be expelled/injected from/into these Ir oxide films, which are very hydrous in nature $[16,25]$.

Fitting the experimentally observed $\Delta m / \mathrm{mol}$ Ir value of $5.5 \mathrm{~g} / \mathrm{mol} \mathrm{Ir}$ to the observed $-68 \mathrm{mV} / \mathrm{pH}$ response, consistent with an anion to Ir site rate of $0.15 \mathrm{HSO}_{4}^{-} /$ Ir, would then suggest that ca. $0.6 \mathrm{~mol}$ of $\mathrm{H}_{2} \mathrm{O}$ per mol of $\operatorname{Ir}(+\mathrm{III}) / \operatorname{Ir}(+\mathrm{IV})$ sites reacted would also be expelled and injected from/into the Ir oxide films, as follows:

$$
\begin{aligned}
\operatorname{Ir}(+ & \text { III }) \text { oxide }\left(\mathrm{H}^{+}\right)_{1.15}\left(\mathrm{HSO}_{4}^{-}\right)_{0.15}+0.6 \mathrm{H}_{2} \mathrm{O} \\
= & \operatorname{Ir}(+\mathrm{IV}) \text { oxide }\left(\mathrm{H}_{2} \mathrm{O}\right)_{0.6}+1.15 \mathrm{H}^{+} \\
& +0.15 \mathrm{HSO}_{4}^{-}+\mathrm{e}^{-}
\end{aligned}
$$

Eq. (5) suggests that the involvement of $\mathrm{H}_{2} \mathrm{O}$ and counter anions in the $\operatorname{Ir}(+\mathrm{III}) / \operatorname{Ir}(+\mathrm{IV})$ reaction is small, and hence, large changes in film volume are unlikely to accompany this reaction. (The latter is consistent with previously reported ellipsometric studies [25], which showed that a film volume change of less than $10 \%$ accompanies the $\operatorname{Ir}(+\mathrm{III}) / \operatorname{Ir}(+\mathrm{IV})$ reaction.) A very similar mechanism has been suggested by Birss et al. [16], who, however, proposed that larger amounts of $\mathrm{H}_{2} \mathrm{O}\left(1 \mathrm{~mol} \mathrm{H}_{2} \mathrm{O} / \mathrm{mol} \mathrm{Ir}\right)$ and counter ions $(0.5 \mathrm{~mol}$ $\mathrm{HSO}_{4}^{-}$and $1.5 \mathrm{H}^{+} / \mathrm{mol} \mathrm{Ir}$ ) are involved in the reaction. The difference between their results [16] and those of the present work (even though their raw data value of $6 \mathrm{~g}$ per mol Ir agrees very closely with the present 5.5) is due to the fact that they fitted their EQCM data to an estimated $-90 \mathrm{mV} / \mathrm{pH}$ response. Such a large dependence is observed only over a broad range of solution $\mathrm{pH}[9,22]$ over which the film equilibrium potential is influenced by several other factors $[12,13]$. It is only in the present research that a more precise measurement of the $\mathrm{pH}$ dependence of $\mathrm{Ir}$ oxide films in low $\mathrm{pH} \mathrm{H}_{2} \mathrm{SO}_{4}$ solutions, i.e. $-68 \mathrm{mV} / \mathrm{pH}$, has been made available.

It is of interest also that the $\Delta m / \mathrm{mol}$ Ir value of 5.5 g per mol Ir found here for potential pulse grown Ir oxide films in $0.4 \mathrm{M} \mathrm{H}_{2} \mathrm{SO}_{4}$ is in good agreement with the value obtained for Ir oxide films grown and studied in $0.2 \mathrm{M} \mathrm{H}_{2} \mathrm{SO}_{4}$ using the potential cycling method [16]. This indicates that (at least small) changes in solution $\mathrm{pH}$ and different growth techniques do not significantly affect the film mass gain/loss accompanying the $\operatorname{Ir}(+$ III)/Ir( + IV) reaction of electrochemically grown, hydrous Ir oxide films.

\subsubsection{The influence of the growth and test solution on the $\Delta \mathrm{m} / \mathrm{mol}$ Ir values}

The mass changes for Ir oxide films grown by potential pulsing in either $0.6 \mathrm{M} \mathrm{HClO}_{4}$ or $0.4 \mathrm{M} \mathrm{HNO}_{3}$ and 
Table 1

Mass differences between reduced and oxidized forms of Ir oxide films grown and studied in a range of acidic solutions

\begin{tabular}{lll}
\hline Growth solution & $\Delta m^{\mathrm{a}} / \mathrm{g}(\mathrm{mol} \mathrm{Ir})^{-1}$ & $\mathrm{H}_{2} \mathrm{O}(\mathrm{Ir})^{-1 \mathrm{~b}} / \mathrm{mol}(\mathrm{mol})^{-1}$ \\
\hline $0.6 \mathrm{M} \mathrm{HClO}_{4}$ & 12 & -0.2 \\
$0.4 \mathrm{M} \mathrm{H}_{2} \mathrm{SO}_{4}$ & 5.5 & -0.6 \\
$0.4 \mathrm{M} \mathrm{HNO}_{3}$ & 6.5 & -0.2
\end{tabular}

\footnotetext{
a Mass differences between the reduced and oxidized Ir oxide film form (i.e. between 0.2 and $0.9 \mathrm{~V}$ vs. SSCE)

${ }^{b}$ Assuming $1 \mathrm{H}_{3} \mathrm{O}^{+}$is expelled and one $\mathrm{H}_{2} \mathrm{O}$ is injected per $\mathrm{Ir}$ site during film oxidation, and vice versa, during film reduction, a -68 $\mathrm{mV} / \mathrm{pH}$ response in the three solutions and that univalent anions are involved in the $\operatorname{Ir}(+\mathrm{III}) / \operatorname{Ir}(+\mathrm{IV})$ reaction (see $\mathrm{Eq}$. (5)).
}

then studied in the same growth solution were also obtained (Table 1). The $\Delta m / \mathrm{mol}$ Ir values for oxides grown and studied in the different solutions were found to decrease in the following sequence: $0.6 \mathrm{M} \mathrm{HClO}_{4}>$ $0.4 \mathrm{M} \mathrm{HNO}_{3}>0.4 \mathrm{M} \mathrm{H}_{2} \mathrm{SO}_{4}$ (Table 1, 2nd column). The mass gain/loss accompanying the electrochemical $\operatorname{Ir}(+$ III) $/ \operatorname{Ir}(+$ IV $)$ reaction is seen to be influenced by the growth solution, consistent with the presumed involvement of electrolyte anions (Eq. (1)) in the $\operatorname{Ir}(+\mathrm{III}) / \operatorname{Ir}(+$ IV) $[10,16]$. As the $E / \mathrm{pH}$ dependence of Ir oxide films grown in these various solutions was determined only in $\mathrm{H}_{2} \mathrm{SO}_{4}$, the complete stoichiometry for the oxidation/reduction reaction can be established only in this medium. However, if a $-68 \mathrm{mV} / \mathrm{pH}$ response is assumed for these oxides in the three solutions, the number of $\mathrm{H}_{2} \mathrm{O}$ per Ir site oxidized/reduced can be estimated (Table 1, 3rd column). This would then suggest that slightly different amounts of $\mathrm{H}_{2} \mathrm{O}$ are involved during the $\mathrm{Ir}(+$ III) $/ \operatorname{Ir}(+\mathrm{IV})$ oxide reaction in different acidic media. This could arise from a somewhat different oxide film structure, nanoporosity or morphology which is developed when Ir oxide is formed electrochemically in different acidic solutions. This was confirmed from both SEM and kinetic studies [20]. However, it is also possible that this difference in the extent of water exchange is a consequence of the nature of the solution. In order to clarify this, the following experiments were carried out.

The influence of the solution anion on the $\Delta m / \mathrm{mol} \mathrm{Ir}$ value was investigated for ca. $3 \mathrm{mC} \mathrm{cm}^{-2}$ Ir oxide films grown only in $0.6 \mathrm{M} \mathrm{HClO}_{4}$ by potential cycling. After growth, the Ir oxide films were subsequently cycled at 20 $\mathrm{mV} \mathrm{s}^{-1}$ between 1.05 and $0 \mathrm{~V}$ for 7 cycles in $0.6 \mathrm{M}$ $\mathrm{HClO}_{4}$ (test solution I, for 10 cycles in $0.4 \mathrm{M} \mathrm{H}_{2} \mathrm{SO}_{4}$ (test solution II) and then back in $0.6 \mathrm{M} \mathrm{HClO}_{4}$ (test solution III) for 10 cycles. In all test solutions, a steady-state $\Delta m /$ mol Ir value was reached by the second cycle. The $\mathrm{CV}$ characteristics of the main peaks were not altered when the Ir oxide films were potentially cycled in any of the three test solutions.

Table 2 shows that larger $\Delta m / \mathrm{mol}$ Ir values of $11.5 \mathrm{~g}$ $\mathrm{mol}^{-1}$ are found in test solutions I and III $(0.6 \mathrm{M}$
Table 2

Typical mass differences for a $3 \mathrm{mC} \mathrm{cm}^{-2} \mathrm{Ir}$ oxide film grown in 0.6 $\mathrm{M} \mathrm{HClO}_{4}$ and then studied in different test solutions

\begin{tabular}{lll}
\hline$\Delta m^{\mathrm{a}} / \mathrm{g}(\mathrm{mol} \mathrm{Ir})^{-1}$ & \\
\hline Test solution I & $\begin{array}{l}\text { Test solution II } \\
\left(0.6 \mathrm{M} \mathrm{HClO}_{4}\right)\end{array}$ & $\begin{array}{l}\text { Test solution III } \\
\left(0.4 \mathrm{M} \mathrm{H}_{2} \mathrm{SO}_{4}\right)\end{array}$ \\
\hline 11.5 & 5 & 11.5 \\
\hline
\end{tabular}

a Mass difference between the reduced and oxidized $\mathrm{Ir}$ oxide film form (i.e. between 0.2 and $0.9 \mathrm{~V}$ vs. SSCE).

$\mathrm{HClO}_{4}$ ) than the $5 \mathrm{~g} \mathrm{~mol}^{-1}$ value seen in test solution II $\left(0.4 \mathrm{M} \mathrm{H}_{2} \mathrm{SO}_{4}\right)$. In fact, the $\Delta m / \mathrm{mol}$ Ir values for Ir oxide films grown in $0.6 \mathrm{M} \mathrm{HClO}_{4}$ and then cycled in $0.4 \mathrm{M} \mathrm{H}_{2} \mathrm{SO}_{4}$ (ca. $5 \mathrm{~g}$ per mol Ir) are similar to the $\Delta m / \mathrm{mol}$ Ir values found for oxides grown and cycled in $0.4 \mathrm{M} \mathrm{H}_{2} \mathrm{SO}_{4}$ (ca. $5.5 \mathrm{~g}$ per mol Ir) (Table 1). This continues to support the counter anion involvement model (Eq. (1)). These results show that the test solution anion, rather than the growth conditions, influences the stoichiometry of the $\operatorname{Ir}(+$ III $) / \operatorname{Ir}(+$ IV $)$ conversion reaction.

\section{Conclusions}

The $E / \mathrm{pH}$ response of hydrous Ir oxide films, determined over a narrow $\mathrm{pH}$ range (ca. 0.5-2) in acidic bisulfate solutions, has been found to be smaller than the previously reported values of ca. $-85 \mathrm{mV} / \mathrm{pH}$ [9,22]. However, the latter value was obtained over a broad range of $\mathrm{pH}$ (acidic to alkaline), over which the classical form of the Nernst equation does not apply $[12,13]$. In this work, a super-Nernstian $E / \mathrm{pH}$ response of $-68 \mathrm{mV}$, was found for Ir oxide films grown in 0.6 $\mathrm{M} \mathrm{HClO}_{4}, 0.4 \mathrm{M} \mathrm{H}_{2} \mathrm{SO}_{4}$ and $0.4 \mathrm{M} \mathrm{HNO}_{3}$ solutions using constant ionic strength $\mathrm{H}_{2} \mathrm{SO}_{4}+\mathrm{Na}_{2} \mathrm{SO}_{4}$ test solutions. This indicates that a small number of anions (ca. $0.15 \mathrm{~mol} \mathrm{~A}^{-1}$ ) per mole of Ir sites converted are involved in the $\operatorname{Ir}(+\mathrm{III}) / \operatorname{Ir}(+\mathrm{IV})$ reaction in sulfuric acid solutions.

The mass change during oxidation/reduction of Ir oxide films, grown and studied in $0.4 \mathrm{M} \mathrm{H}_{2} \mathrm{SO}_{4}$, was also fitted to the experimental $E / \mathrm{pH}$ response of -68 $\mathrm{mV} / \mathrm{pH}$, suggesting that $0.6 \mathrm{~mol} \mathrm{H}_{2} \mathrm{O}$ per Ir site oxidized/reduced are injected (expelled) into (from) these films. The mass difference between the reduced and oxidized form of Ir oxide films has been found to be influenced primarily by the solution anion used to study the oxide, and to be almost independent of the growth conditions used (pulsing vs. cycling method or growth solution). This suggests strongly that both protons and anions are expelled from the oxide film during oxidation, and injected during film reduction. 


\section{Acknowledgements}

Financial support from the Natural Science and Engineering Research Council of Canada and the University of Calgary is gratefully acknowledged.

\section{References}

[1] G. Gampet, B. Morel, M. Bourrel, J.M. Chabagno, D. Ferry, R. Garie, C. Quet, Mater. Sci. Eng. B8 (1991) 303.

[2] E. Kukuchi, K. Iiada, A. Fujishima, K. Itoh, J. Electroanal. Chem. 130 (1993) 303.

[3] S. Trasatti, P. Kurzweil, Platinum Metal Rev. 38 (1994) 46.

[4] A. Rudge, J. Davey, I. Raistrick, S. Gottesfeld, J.P. Ferraris, J. Power Sources 47 (1994) 89.

[5] L.S. Robblee, J.L. Lefko, S.B. Brummer, J. Electrochem. Soc. 130 (1983) 731

[6] D.N. Buckley. L.D. Burke, J. Chem. Soc. Faraday 171 (1975) 1447.

[7] D.A.J. Rand, R. Woods, J. Electroanal. Chem. 55 (1974) 375.

[8] P.G. Pickup, V.I. Birss, J. Electroanal. Chem. 220 (1987) 83.

[9] L.D. Burke, D.P. Whelan, J. Electroanal. Chem. 162 (1984) 121.

[10] P.G. Pickup, V.I. Birss, J. Electroanal. Chem. 240 (1988) 171.
[11] R. Kotz, C. Barbero, O. Haas, J. Electroanal. Chem. 296 (1990) 37.

[12] C.E.D. Chidsey, R.W. Murray, J. Phys. Chem. 90 (1986) 1479.

[13] P.J. Peerce, A.J. Bard, J. Electroanal. Chem. 114 (1980) 89.

[14] V.I. Birss, M. Chang, J. Segal, J. Electroanal. Chem. 355 (1993) 181.

[15] T. Tjarnhage, B. Skarman, B. Lindholm-Sethson, M. Sharp, Electrochim. Acta 41 (1996) 367.

[16] V.I. Birss, H. Elzanowska, S. Gottesfeld, J. Electroanal. Chem. 318 (1991) 327.

[17] P.G. Pickup, V.I. Birss, J. Electrochem. Soc. 135 (1988) 126.

[18] D.J.G. Ives, G.J. Janz, Reference Electrodes, Academic Press, New York, 1961.

[19] C. Bock, V.I. Birss, Proceedings of the Electrochemical Society, Electrochemically Deposited Thin Films III Symposium, San Antonio, Texas. October 1996

[20] C. Bock, PhD Dissertation, University of Calgary, Calgary, AB, 1997

[21] V.I. Birss, C. Bock, H. Elzanowska, Can. J. Chem. 75 (1997) 1687.

[22] M.F. Yuen, I. Lauks, W.C. Dautremont-Smith, Solid State Ionics 11 (1983) 19.

[23] P.G. Pickup, V.I. Birss, J. Electroanal. Chem. 240 (1988) 185.

[24] G. Sauerbrey, Z. Phys. 155 (1959) 206.

[25] S. Gottesfeld, S. Srinivasan, J. Electroanal. Chem. 86 (1978) 89. 